International Journal of Innovation Management

Vol. 7, No. 1 (March 2003) pp. 95-129

(C) Imperial College Press

\title{
HAVE PROCESS INDUSTRIES SHIFTED THEIR CENTRE OF GRAVITY DURING THE 90s?
}

\author{
DIANA CHRONÉER \\ Division of Industrial Organization \\ Luleå University of Technology \\ S-971 87 Luleå, Sweden \\ Diana.Chroneer@ies.luth.se \\ Received 18 December 2002 \\ Revised 10 February 2003 \\ Accepted 13 February 2003
}

\begin{abstract}
Product development is often seen as a main tool for competitiveness in organizations. In process industries, like steel and paper, process and product development are seen as an integrated part. Product development has often been the result of a process development. Heavy investments and costly production give process a priority role in product development. The role of customers and suppliers in development work has increased for process-based companies. This change will have implication on how to organize and manage development in the traditional upstream companies. Therefore, this article presents results that show some of the implications of the changed situation for Swedish processbased companies. The article also emphasizes that there are indications of a shift of traditional upstream companies' centre of gravity due to the changed perspective in development work, towards customer focus.
\end{abstract}

Keyword: Product development; customer-orientation; process industries; centre of gravity.

\section{Introduction}

What has happened in the Swedish process industries during the 90ths concerning product development work? How do they manage the turbulent change from being process-oriented towards product-oriented in development work? This article emphasizes that there are indications of a major change during the 90ths in development focus for process industries in Sweden and this change will have an impact on the industries' centre of gravity.

The competitive environment for companies in process industries is undergoing a fundamental change in Sweden. In recent years there have been quite a number 
of mergers and acquisitions in e.g. the Swedish chemical industry in order to rationalize production, to optimise research and development and to facilitate international marketing. For most of the high-volume chemicals there is just one main manufacturer today per specific product. The same goes for the steel industry; growth in niche areas has been more rapid than for steel market in general and deliveries of these products have increased substantially during the most recent ten-year period. A lot of effort is put into an increasing focus on developing new applications in co-operation with customers.

What role does product development play in Swedish process industries today and in the future? Process industries like steel and paper industries have traditionally had a process-oriented view in product development projects. The focus has been on the development of their production processes. Therefore, product development has often been the result of major process development. High investments in machines and equipment have promoted economy-of-scale and production of high-volume products. Product development has not been of primary interest due to a quite low value-added.

Within the last decades, the rapid rate of technological change, shortened product life cycles, and increasing global competition have made product development a critical concern of a great number of companies in a range of industries. Today, suppliers and customers are an increasingly important resource for manufacturer. Research shows that building bridges between functions and to suppliers and customers increased the likelihood of success for the company. These bridges can take the form of cross-functional teams with $R \& D /$ manufacturing/marketing integration (Kahn, 2001; Olson et al., 2001, Song et al., 1998; Song et al., 1997; Fischer et al, 1997) and $R \& D /$ marketing integration (Ottum \& Moore, 1997; Song et al., 1996; Griffin \& Hauser, 1996; Griffin \& Hauser, 1993). Other forms of collaboration are strategic partnerships (Comer \& Zirger, 1997; Littler \& Levrick, 1995; Magrath \& Hardy, 1994), which can be with suppliers (Swink \& Mabert, 2000) and customers (Kärkkinen et al., 2001; Mello, 2001; Butscher \& Larker, 2000; Gruner \& Homburg, 2000; Campbell \& Cooper, 1999).

Ragatz et al. (1997) point out that suppliers can have a large and direct impact on cost, quality, technology, and speed. Research shows that collaborations in all forms are increasingly playing a major role in product development. But this increased need of collaboration with various actors will imply improved integration of resources and activities for the companies. To have a network perspective in development work can facilitate the awareness of needed links to both internal and external actors. A network perspective means focusing on relationships between actors, activities and resources (Håkansson, 1990). In order to obtain a better understanding of the need of changes concerning organization and 
management of development in process industries, a possible starting point is to have a network perspective.

What makes a company choose a certain strategy or perspective in product development issues? According to Galbraith (1983), a company and its management are formed by the tradition and the values of the industry it is belonging to. But if markets and customers change for process industries what implication will this have on the company's position in the supply value chain? If customers outsource part of their business to suppliers, what impact does it have on a company's actions in its value chain and its organization of product development teams in the future?

Galbraith (2002) also illuminates that a recent trend in business strategy is to offer solutions to customers instead of just physical products. This means that the suppliers must create an organization that can package and deliver the solutions. Galbraith points out that the company must add a customer-centric component to its organization and then integrate that component with its productbased structure.

This article will firstly discuss the implication a change of perspective in development for process industries will have on the company's position in the supply value chain. Secondly, the article will debate the changed need of networks and improved integration of resources and activities for companies within process industries.

The changed position in the supply value chain will be debated in accordance to the concept of centre of gravity developed by Galbraith (1983). Process-based companies are usually characterized as upstream companies, i.e. have standardized products and focus in process development but is this true today? Have traditional process industries undergone a shift of centre of gravity, towards the "consumers"? Figure 1 illustrates the framework of the research. The market/customer needs have changed for process-based companies. This change will have implication on the company's position in the supply value chain, which will then need improved integration mechanism to its actors involved in development work. But a new organization that creates and delivers solutions to its customers is not easily managed, according to Galbraith (2002). Process-based companies cannot completely abandon their traditional process-oriented view due to their high investments in their production processes. Instead they tend to balance between the two perspectives, process versus customer-oriented development.

The objective of the study is to emphasize the change of perspective in development projects for process industries, from process-orientation to customerorientation in development projects. The following two research questions address this objective: 


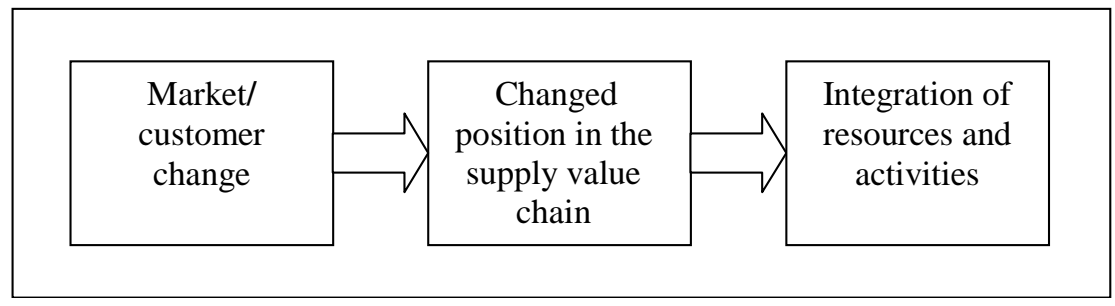

Fig. 1. The framework of changed situation for process-based companies.

- What has changed in development concerning project work and collaboration for companies in various process industries during the last decade?

- What are the implications of this change of a more customer-oriented view in development for process industries?

\section{Manufacturing Industry versus Process Industry}

Product development in process industries has other aspects than that of other manufacturing industries. It is for a larger extent focused on the improvements of product properties, the improvements of product quality, and the development of more environment-friendly products.

Until the end of 1970's, product development has received relatively limited attention in process industries. But today, this situation is changing due to an increased international competition and market changes. Customer demands specific products with special material properties. This increased demand of specific products has led to an increased interest in product development issues for process industries. This suggests that there is a change from a traditional perspective on product development towards a more customer-oriented view for companies dealing with high-volume products (Huang et al., 2002).

There is a challenge for the $21^{\text {st }}$ century for process industries (and other industries) to survive and to maintain profitable in rapidly changing markets. But to achieve this, it is required to understand the changing environment and to use these changes to their advantage. It is necessary for process-based companies to be able to anticipate customer needs as well as technology that respond to them.

A product in process industry is often characterized as of low technology, long product life cycle, fairly long product development time etc. However, this is about to change for Swedish companies dealing with development of material properties. But it is not easily changed. The underlying assumption is that since product and process are symbiotically related in the production system, then fundamental changes in the one must incite and parallel fundamental changes on the other (Etienne, 1981). 
A product in process industry is very complex due to its material property complexity, e.g. a tire is not simply a "black donut" but the end result of complex chemical and engineering processes, which must resist extremes of heat, cold, and stress (Ita \& Gross, 1995).

Process industry today must find a way to develop the right products, i.e. to develop niche products and develop value-added products. This means improved functionality, features, and performance. Companies need to bring the new product to market faster. Once they have identified the right product, they need to be able to shorten the development cycle. One way is to make better, more efficient use of technology and human resources (Harkins \& Dubreuil, 1993). This also requires sustainable networks with both suppliers and customers.

However, process industries are often characterized with a process-oriented perspective on product development. They have primarily been interested in the technological solutions of the production process. These solutions are often a link in an optimisation of the production process, i.e. finding a more cost-effective process and can give implications in product development projects. Product development will then be a secondary result of the change of the production process, i.e. product development is defensive (Utterback, 1996).

In a study concerning product development in the chemical and oil industry, Heinonen (1994) summarizes some special characteristics of process industry.

- Production is usually continuous and parallel, which complicates the cost calculation of individual products.

- High investment costs hinder progress, which leads to an aim to maintain existing equipment.

- A problem of slowness and inflexibleness in project realization, owing to the long period of time the investment demand, leads to cautiousness.

- Problems caused by the big size of the industry and the difficulty to produce special products.

- Great internal and mutual dependencies among product groups, products, product properties, raw materials and processes.

- Optimisation problems that are related to product yield to change production structure according to changing demand causes difficulties.

- The development of products and processes in process industry is subject to co-operation and coordination with equipment suppliers.

\section{The differences}

There are some major differences between process industries and other manufacturing industries. 
One major difference is that the process industry, in general, has very inflexible and costly equipment. The production process is often unique for the purpose of manufacturing a specific product. The products that are manufactured are often interdependent. Changes of material properties in the raw material affect the entire product group.

Another difference between process industry and manufacturing industry is the emphasis on material properties and process technology for process industry. There is an absence of the function engineering design, i.e. design of product architecture, building physical prototypes in product development in process industries. However, in process industries there is a close interaction between product and process development. It can be difficult to separate product development from process development. Product development is often done in a laboratory and is often a result of process development. The process technology often states the boundaries within which product development can be performed.

A third difference between the manufacturing industry (i.e. pieces-goods industry) and process industries is the objective for product development. Some of the key product development objectives for the manufacturing industry are; market introduction date, product unit cost, product performance, and development project expense (Smith \& Reinertsen, 1998). While the main objectives for process industries can be to improve product properties, to improve product quality, and to develop more environment-friendly products.

However, customer-orientation and improvement of company product development capability in process industry have been emphasized the last decade. It can be difficult to separate resources for R\&D in process industries because product and process development are so inter-linked. Lager (2002) means that there should be a sharper distinction between product and process development activities per se, but they should not be completely separated.

\section{Centre of Gravity}

Galbraith's ideas of the concept of centre of gravity rest on the fact that an organization has a driving force or a centre of gravity (Galbraith, 1983). This centre of gravity arises from the firm's initial success in the industry in which it grew up. According to Galbraith, a company and its management are formed by the tradition and the values of the industry it is belonging to, it all depends on the position in the supply value chain ${ }^{1}$ (see Fig. 2). Galbraith means that the

${ }^{1}$ For discussion of the "value chain", see Porter, (1985). 


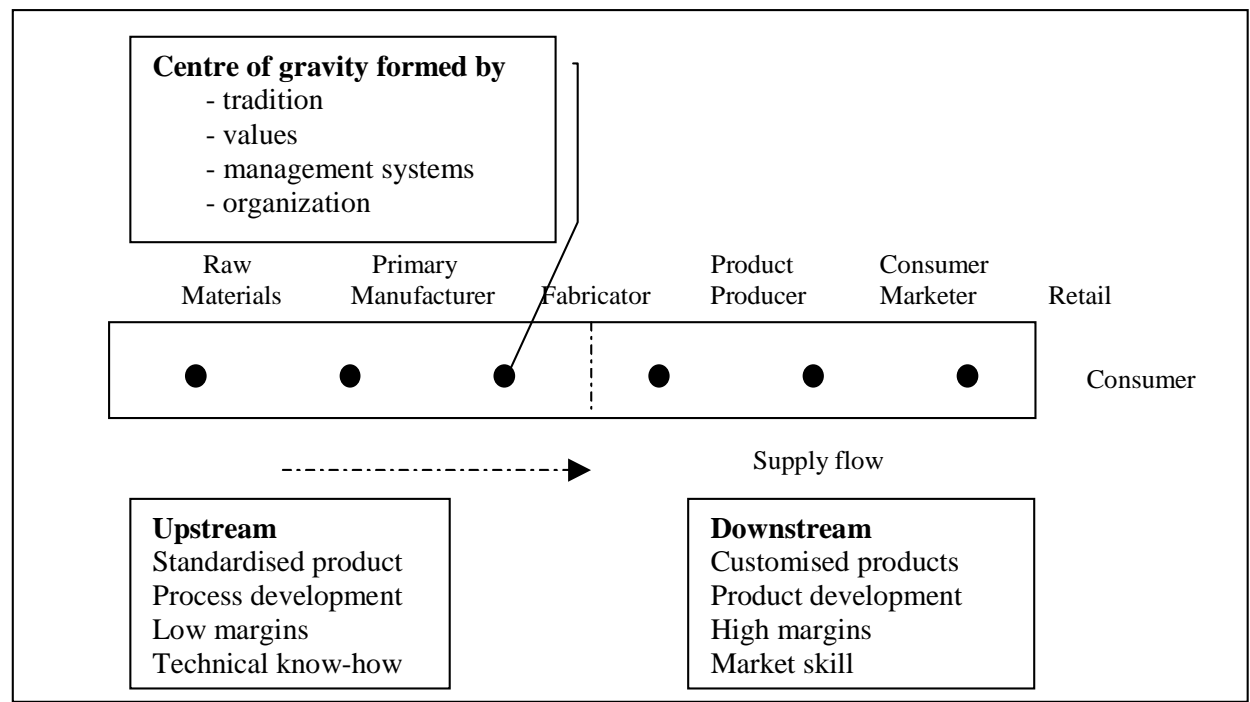

Fig. 2. A value-added supply chain in a manufacturing industry (Developed from Galbraith \& Kazanjian, 1986). The line splitting the chain into two segments divides the industry into upstream and downstream halves.

companies' values, their management systems, and their organization are all shaped by "the stage of initial success". The company has established an anchor or a centre of gravity by starting operations in a particular industry at a particular stage of that industry. This point is important, because each stage of any industry has different success factors. Strategic changes will then take place through moves around and from this centre of gravity.

Every industry has a value-added supply chain, a sequence of activities that transforms raw materials into end product or service. The value-added supply chain in a manufacturing industry begins with raw material extraction stage, which supplies crude oil, iron ore or logs to the second stage of primary manufacturing. The second stage is a variety-reducing stage to produce a standardized output like petrochemicals, steel, and paper pulp. The third stage fabricates commodity products from primary material. Fabricators produce e.g. polyethylene, sheet steel, or cardboard cartons. The fourth stage is the product producers, who add value usually through product development. The following stage includes the manufacturer and marketer of consumer products. In the last stage come the distributors and the retailers, who sell to the final consumer. These companies add value by creating time and place utility.

The chain can be divided into two halves, i.e. upstream and downstream companies, and each stage has different success factors. 
There are some fundamental differences that illustrate the contrast between upstream and downstream companies. Galbraith means that downstream stages add value through producing a variety of products to meet varying customers needs. The downstream value is added through advertising, product positioning, marketing channels, and $R \& D$.

Galbraith points out those characteristics as standardization, line-driven organization, process innovation, capital intensive, and technological know-how illustrate upstream companies. In contrast, downstream companies are more concerned about customisation, line/staff (they produce multiple products that require larger staffs), product innovation, people intensive (critical skills centre on human resource management), and market skills (Galbraith \& Kazanjian, 1986).

Can a company's centre of gravity change? Ilinitch and Zeithaml (1995) have operationalised and tested Galbraith's centre of gravity theory. One of the implications from their study point to the fact that firms operating in business which are far removed from their historical centre of gravity, may be inappropriately applying the values and routines which contributed to their initial success.

The term process industry is often associated with the characteristics of standard product, low-cost, process innovation, high investments in process technology, and high technological know-how, i.e. characteristics of upstream companies. But can companies characterized as process industry maintain their path of producing low-cost products and rely on their superb technological competence? This article argues that there has been a shift in Swedish process industries' centre of gravity. That is, old values and tradition has broken when it comes to be competitive today. It is emphasized to develop niche products and to incorporate customers into development work.

What are the consequences of a change of centre of gravity? This change is incremental and it is the people that work with development work that are the ones that first starts the process. However, it is important that this "mental" shift transfers to be stated as a strategic shift, that the development get the appropriate tools and techniques to form suitable networks and base for development.

This article points to the fact that there is a need for a new "way-of-thinking" regarding the division of companies in upstream vs. downstream. However, not all processed-based companies need to change their centre of gravity. There are companies that can continue to manufacture a high-volume product, but the requirement for that it to be a large company that can maintain cost-effectiveness. For example, the steel crisis in the mid-70s gave rise to a period of restructuring in Sweden, with merger of stainless operations. The last decades for Swedish process-based industries indicate that there have been mergers and acquisitions 
that enable the companies to be more focused on their development task in specific niches.

\section{Strategic change}

Strategic change is a subject of substantial research. Rajagopalan and Spreitzer (1996) have made a comprehensive review of the strategic change literature. They summarize that there are several characteristics that can have an effects on strategic change, environmental variables (e.g. deregulation) and organizational variables (e.g. firm size, age, and top management characteristics). But what implies a strategic shift and a change of centre of gravity for a company? Galbraith and Kazanjian (1986) give a summary of the main strategic changes a company can perform.

One change that an organization makes is to vertically integrate within its industry. To move backwards to guarantee sources of supply and secure bargaining leverage on vendors, or/and to move forward to guarantee markets and volume for capital investments and become customer to feed back data for new products. This initial strategic move does not change centre of gravity because the prior and subsequent stages are usually operated for the benefit of the centre-of-gravity stage.

The concept of centre of gravity, according to Galbraith and Kazanjian (1986), allows a discussion of strategic changes in other ways, some are more difficult than others. They introduce four different dimensions of diversity. The first (by-products diversification) is the number of different industries in which a company operates. This measure of diversity is the simplest and will distinguish among by-product diversifiers. But the strategic implementation problems occur when the new industries are different from those in which the company already operates.

The second (related diversification) measure of relatedness assumes that a company operated at the same centre of gravity, but entered businesses where other business functions were different, such as process technology, customer buying behavior, and so on.

The third (linked diversification) measure is the number of different centres of gravity at which a company operates. The company must learn not only new business but also new ways of doing business.

The fourth measure is the distances between the centres; that is, differences between ways of doing business are proportional to the distance on the industry supply chain. The final type of strategic change is to diversify into unrelated business. 
However, another possibility is for an organization to stay in the same industry but change its centre of gravity in that industry. Galbraith points out some attempts of chemical companies to move downstream into higher margin, proprietary products. To move away from low margins and high capital intensity, it implies a shift in the centre of gravity of the company.

Have process industries in Sweden changed their strategy towards diversification or have they changed their centre of gravity? Rumelt (1986) means that diversification as a strategy is defined as the firm's commitment to diversity per se; together with the strength, skills or purposes that span this diversity, demonstrated by the way new activities are related to old activities. Further, he points out that the essence of diversification can be described as "reaching out" into new areas, which requires development of new competences or augmentation of existing ones.

The following hypotheses are posed to test the changes and the current position of Swedish process-based companies:

Hypothesis 1: Process industries in Sweden have moved downstream, away from low margins and high capital intensity into higher margins, proprietary products. It implies a shift of the companies' centre of gravity.

Hypothesis 2: Process industries in Sweden have shifted their "upstreamthinking" to "downstream-thinking", which implies new managerial systems and closer links to customers.

The indicators that are used to indicate a "shift of mind" for Swedish process industries are chosen after some of Galbraith's characteristics of upstream and downstream companies. They are type of product, development focus, customer collaboration in development projects, and cross-functional teams, see Table 1. The fourth indicator, the use of cross-functional teams, tests indirectly Galbraith's definition of line-driven organization vs. line/staff. It means that organizations are different. The upstream companies are functional and line-driven that is staff are used in supporting roles. The downstream company with multiple products and markets learns to manage diversity that is resources need to be allocated across products and markets.

This article argues that traditional Swedish "upstream companies" have changed their "centre of gravity". This change will have implication on how to organize and management development work, but this is not easily achieved due to old tradition and values. So, how has processed-based companies managed this great change? Is it possible today to divide companies into upstream vs. downstream according to Galbraith's definition? 
Table 1. The indicators of a change of gravity.

\begin{tabular}{ll}
\hline \hline \multicolumn{1}{c}{ Variables } & \multicolumn{1}{c}{$\begin{array}{c}\text { Galbraith's Upstream/Downstream } \\
\text { Definition }\end{array}$} \\
\hline Type of product & Standardize/Customize \\
Development focus & Process/Product innovation \\
Customer cooperation in development projects & Sales push/Marketing pull \\
Cross-functional teams & Supporting roles/Manage diversity \\
\hline \hline
\end{tabular}

In summary, a firm's centre of gravity has a strong influence on diversification options and success. Centre of gravity, in addition the degree of diversification, is a prime determinant of organizational structure, systems, and processes. However, if there is a change in a company's perspective on product development projects, i.e. if it emphasizes customer needs and demands it will be affected by the company's centre of gravity. The routines, the working procedure etc. are well rooted in the tradition of being an upstream company. This tradition will therefore be an obstacle in the change of the organization and the management of product development projects.

\section{Methodology and Objectives}

The purpose of this article is to investigate process-based companies' (i.e. upstream company) strategy shift towards product development and its affect on the companies' centre of gravity. This change will have implication how to organize and management development work. 50 companies in various industries, i.e. ore, steel, pulp/paper, chemical, rubber, plastics, and food/dairy participated in the research. However, the purpose is not to state that there has been a strategic shift but to investigate some of the indications that process-based companies might be headed towards a strategic shift. Since the focus in this research is on current development work and project changes during the $90 \mathrm{~s}$, it is not possible to affirm that the companies studied have actual changed their strategy.

The research is divided into two parts. The first part of the research consists of an investigation of the process-based companies' current development work. This part analyses the four indicators: product type, development focus, customer collaboration, and the use of cross-functional teams for each of the companies. These four indicators should be different in an upstream vs. downstream company according to Galbraith's (1983) definition of "upstream" and "downstream".

The second part consists of a comparison between the companies' strategy statements of the year 1985 and the year 2000. The choice of a 15-year-period 
is due to the fact that the second half of the 1980s was a period of great changes for various industries in Sweden. This part of the research gives indications if the companies have changed their statements during a period of time and relates it to stated changes in development focus and organization (stated in part one of the research). However, an analysis of annual reports does not give proof of actual strategic changes but it gives some indications. Further, the second part enables a categorization of the companies as an "upstream" or a "downstream" company in 1985, according to Galbraith's definition. There was also an analysis of the companies' product range in accordance to Rumelt's concept of diversification. Had the companies diversified their products or found new markets? However, this analysis just consisted of if the companies had changed their product mix or if it was the same in 1985 and in 2000.

The change of focus in development will imply a change of gravity, i.e. that other aspects are of interest in development work than low margins with capitalintensive equipment. This means that the company must implement and understand other working methods and create suitable networks. As a result the change of perspective must be enhanced to a managerial level of strategic renewal.

\section{Data collection and analysis}

The data collection is also divided into two parts. The first part consisted of a major investigation of how 50 companies in various industries, i.e. ore, steel, pulp/paper, chemical, rubber, plastics, and food/dairy, conduct their development and their needs in the future concerning both organization of development and information collection, distribution, and storing. The criteria for selecting the companies were that they should be part of the "traditional" process industry, i.e. produce a product that is regarded as a "low-cost product". However, due to scarcity of available companies in the selected industries, the total amount of companies is quite low. The sample of companies was taken from industry lists, which identified those companies that are active in the specific industries mentioned above. Representatives of Swedish branch organizations also came with suggestions of existing companies. Companies were initially contacted by telephone to ensure that they had/were involved in development projects, to identify the key respondents, and to solicit cooperation. 50 companies agreed to participate in the research (from 55). To ensure reasonable reliability of the data, respondents received a copy of their answers of the questions where they could make alterations etc. Altogether 50 companies participated with one respondent at each company. Since the purpose of the study was to investigate current development work, changes during the $90 \mathrm{~s}$, and future needs to development projects, the respondents needed to have deep insights in development work. 
Table 2. Number of companies in sample by type of industry and size.

The number of employees is the determinant of the size of the company.

\begin{tabular}{lcccr}
\hline \hline Type of Industry & \multicolumn{4}{c}{ Size of the Company } \\
\cline { 2 - 5 } & $\begin{array}{c}\text { Small } \\
\text { (no. employees } \\
<100)\end{array}$ & $\begin{array}{c}\text { Medium } \\
(100 \leq \text { no. employees } \\
<500)\end{array}$ & $\begin{array}{c}\text { Large } \\
\text { (no. employees } \\
\geq 500)\end{array}$ & Total \\
\hline Ore & 0 & 0 & 2 & 2 \\
Steel & 0 & 1 & 8 & 9 \\
Paper & 0 & 0 & 7 & 7 \\
Chemicals & 6 & 6 & 3 & 15 \\
Rubber & 1 & 2 & 0 & 6 \\
Plastics & 2 & 1 & 6 & 4 \\
Food/Dairy & 0 & 12 & 29 & 7 \\
Total & 9 & & 30 \\
\hline \hline
\end{tabular}

Therefore, most of the respondents were R\&D managers and in smaller companies some were project leader or member of product development project. Table 2 gives the distribution of the companies in each branch sector and their size. The companies are divided into three groups: small, medium and large depending on the number of employees.

Data was gathered from structured telephone interviews with open-ended questions. This enabled a rich understanding of the companies' current development work that could be used to explain certain phenomenon. Most of the interviews were recorded and typed. All interview materials were then coded with a software technique called "Non-numerical Unstructured Data Indexing Searching and Theorizing" (N5). It is a computer package designed to aid users in handling non-numerical and unstructured data in qualitative analysis. The texts were first coded with nodes and organized in a "tree" structure. This enabled thorough analyses of the material. Since the questionnaire format was based on open-ended questions, and the respondents, in some cases, found it difficult to grade the answers, they were coded in the frame of dichotomy in SPSS 11.0 (Statistical Package for the Social Sciences). SPSS was a tool that enabled a summary of the answers that then could be analysed. But the basic analysis of the material is a combination of both a qualitative and a quantitative analysis. There is no statistical significant test done due to the purpose of the research is to illustrate some of the indicators of a "changed mind" for traditional process industries.

The second part consisted of a comparison of the 50 companies' strategies (i.e. the Groups' strategies), in the seven process-based industries, over a period 
of 15 years (facts from annual reports in 1985 and in 2000). The comparison consisted of finding key words like product development, higher margins, valueadded products, and customer need in the strategy statements from 1985 and 2000. The implication that there has been a change of mind for the company is when the company emphasizes some of these key words in the year 2000 and not in the year 1985. Had the companies diversified their products or found new markets? This analysis consisted of a comparison the companies' product mix in 1985 and in 2000 (data from annual reports). However, no deeper conclusions can be derived from the annual reports. They are merely used as an illustration of a possible change of strategy. Further sources are required to enable deeper analysis if the companies actually have changed their strategies.

\section{The framework of the research}

The main framework of the research is to investigate how the four factors: product type, development focus, customer collaboration, and the use of crossfunctional teams in development projects are indicators that upstream companies are headed towards the same perspective in development issues as downstream companies. This change of perspective will imply a change of gravity, i.e. that other aspects are of interest in development work and this means that other working methods and networks must be implemented and understood. As a result the change of perspective must be enhanced to a managerial level of strategic renewal (see Fig. 3). This is however a continuous process, a strategic shift will have an impact on the product type, development focus, the need of customer collaboration in projects, and the use of cross-functional teams.

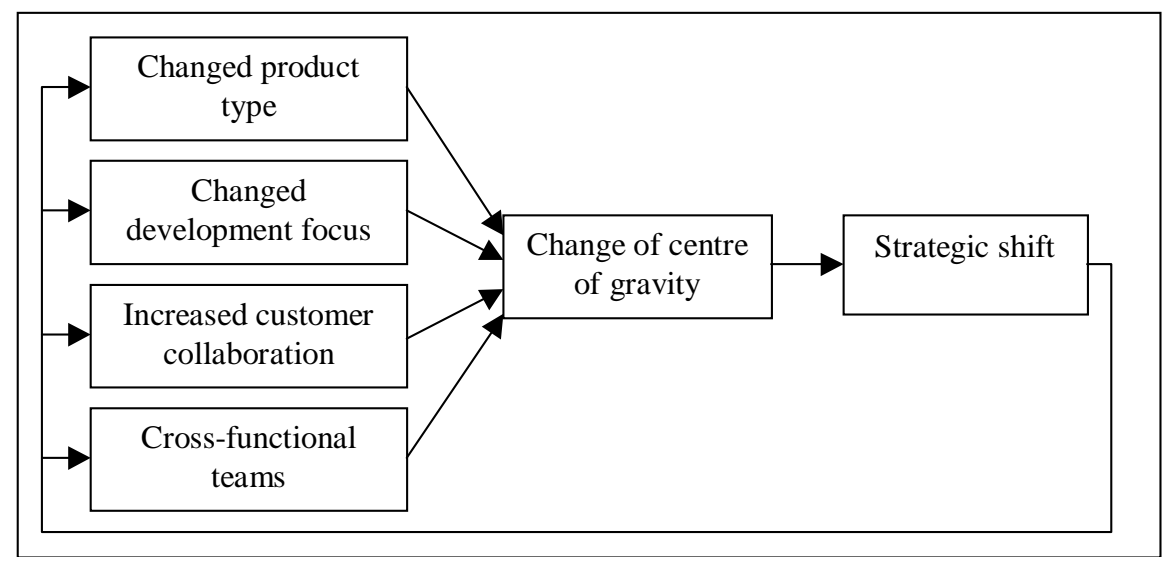

Fig. 3. The framework of the research. 


\section{What Are The Results?}

The main question of the research is if Swedish process industries have changed their centre of gravity during the last decade, and if so, is there a need of improved integration of resources and activities? To be able to answer the question, the results are presented in four parts; changes for the companies during the 90ths (1), the companies' position in the supply value chain (2), centre of gravity shifts for the companies (3), and finally the companies' way to manage the change (4). Figure 4 illustrates the outline of the results.

The first part of the results presents what explicit have changed for the companies during the last decade. There has been a great deal of changes for companies characterized as process industry in Sweden during the last decades. A brief summary of the respondents' comments about changes during the 90s is followed below. Their comments are divided into following areas; product development, product concept, organization, project work, and customer/supplier relations, see also appendix A.

Product development: Develop better products due to new knowledge; change towards niche products and increased number of niche products; development of new properties; increased product development focus and efforts.

Product concept: Sell development hours; integrate forward in the value chain with assembly and packaging combined to the product; work with customers processes; sell a complete concept — are "problem solvers"; increased responsibility of customers' development; increased personal service to customers; learn them to use the product.

Organization: Now project organization with project leader; flat organization; project organization; organization towards specialization of material; organizational

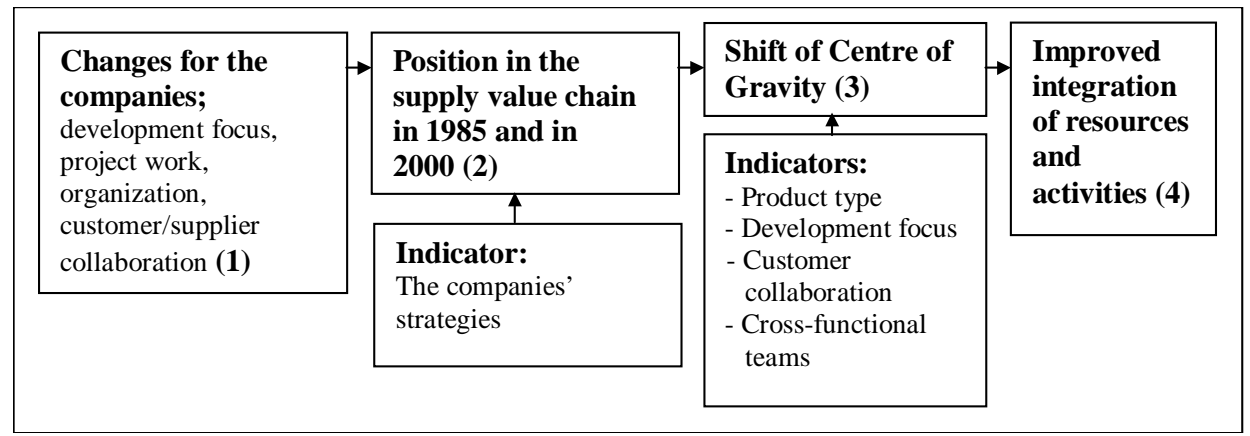

Fig. 4. The outline of the results. 
changes toward focusing the business - clear link between development and sale personnel; technique divisions to enable focusing in product areas; direct link between development and marketing, marketing, sale and product development work closely together to make product development more effective; division in three R\&D sections: product development, process development and strategic development plus a section that do customer projects in cooperation with the other sections; decentralized R\&D organization, a Technology centre work closely with development at production sites, merger; changed product development from technical department to marketing department; sale organization contact with customers' engineers, education of customer engineers.

Project work: Team-building; the Group has common IT platforms that enable project sharing; change in documentation of projects; project management, planning and control of projects; increased market input in development projects; changed working methods, cross functional teams; made product developer to market technicians - to catch customer needs and communicate with procurement and technique - at customer databases to systematize projects.

Customer/supplier collaboration: Customers are involved earlier in projects; work more closely with customers and supplier; development projects with suppliers, more flexibility and quicker response on customer's need; raw material suppliers are viewed as a resource that can decrease product development time; increased customer collaboration to gain insight of customer problems and their product development; more efficient input from customers to projects.

The second part of the results presents the companies' positions in the supply value chain in 1985 and in 2000. The companies are categorized in accordance to Galbraith supply chain (1983). But to enable to decide the companies' position in the chain, the companies are first divided into two groups: upstream and downstream companies. The companies' product types in 1985 determine the categorization and position. This categorization is based on Galbraith's spectrum of product characteristics (the degree of value-added) in combination with stated development intentions in 1985. Table 3 shows the distribution of the division and Fig. 5 illustrates the companies' position in the supply value chain and Galbraith's product characteristics. Every circle indicates one company in the study, with a total of 50 companies.

Some examples of the product type in each industry are as follows: Ore: Upstream - metals, minerals, pellets.

Steel: Upstream - magnetic materials, long steel products, stainless steel, steel sheet. Downstream - value-added aluminum profiles.

Paper: Upstream - Pulp, paper. Downstream - corrugated cardboard. 
Table 3. Number of companies in sample by type of industry and number of upstream vs. downstream companies (divided after the companies' product type in 1985).

\begin{tabular}{lcc}
\hline \hline \multirow{2}{*}{$\begin{array}{c}\text { Type of } \\
\text { Industry }\end{array}$} & \multicolumn{2}{c}{$\begin{array}{c}\text { Traditional Characteristics } \\
\text { of the Companies }\end{array}$} \\
\cline { 2 - 3 } & Upstream & Downstream \\
\hline Ore & 2 & 0 \\
Steel & 7 & 2 \\
Paper & 4 & 3 \\
Chemicals & 9 & 6 \\
Rubber & 2 & 4 \\
Plastics & 0 & 4 \\
Food/Dairy & 4 & 3 \\
Total & 28 & 22 \\
\hline \hline
\end{tabular}

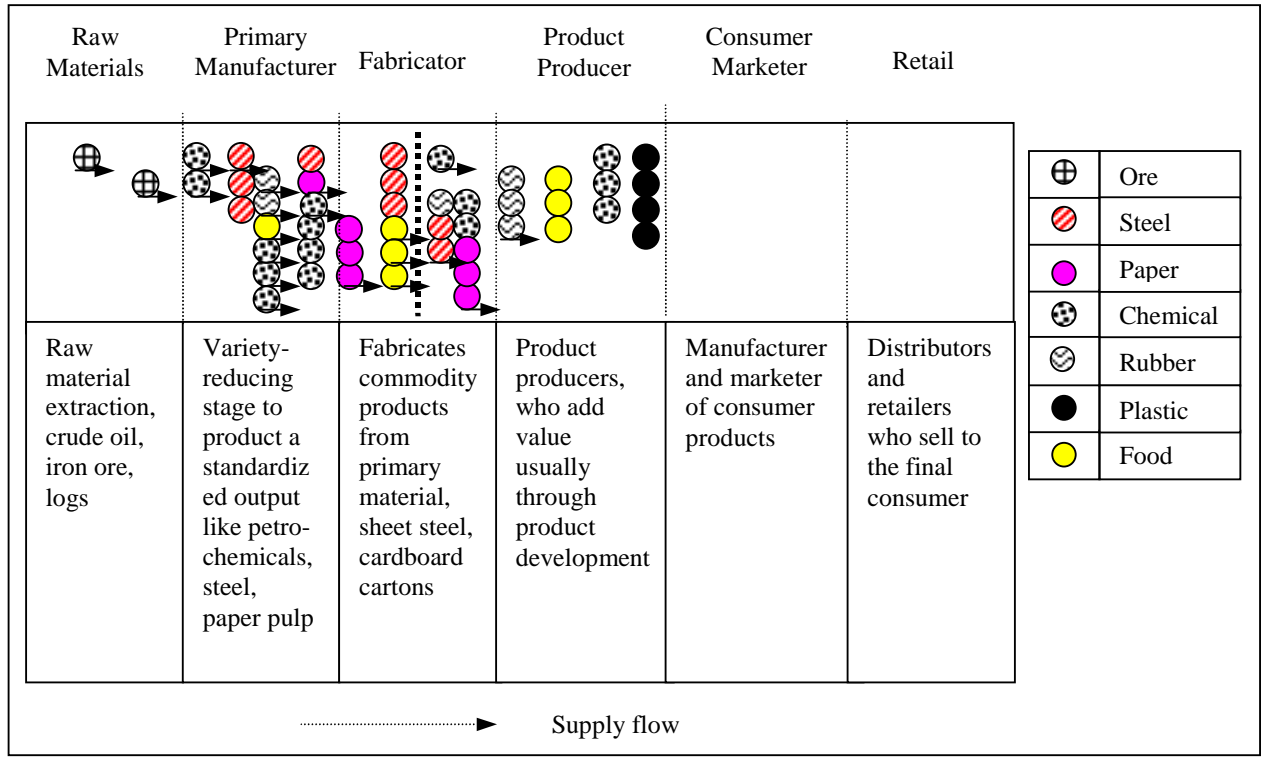

Fig. 5. The position of the companies (50) in Galbraith's model of the supply chain. (The arrows imply that the company has changed its strategy from the year 1985 to the year 2000 . These companies emphasize value-added products, higher margins, and product development in their strategies in the year 2000, which they did not do in the year 1985). 
Chemicals: Upstream - starch, lubricate, paint, chemicals for pulp and paper industry, oil. Downstream - subcontracted work.

Rubber: Downstream - tires, injection moulded components, compression moulded products in polymer materials.

Plastics: Downstream - fibre composite components, PVC-compounds.

Food/Dairy: Upstream - dairy products, sugar. Downstream - consumer products, agro-chemicals.

Have the companies changed their strategies during a 15 -years-period? Figure 6 shows that, from the sample of 50 companies, a total of 22 companies (44\%) have some indications of a customer-focused strategy and a total of 23 companies (46\%) do not have any indication in 1985. The comparison of the strategy statements indicate that 21 out of 50 companies (42\%) that did not have a customer-focused strategy in 1985 had changed the strategy statements in 2000, i.e. towards finding products with higher margins and satisfying customer needs. 17 out of 28 upstream companies indicate a change of strategies (61\%). Nine upstream companies already had customer-focus in 1985 . Five of the companies do not have any records available that can be compared. The purpose of this paper is not to make a comprehensive analysis if the companies have actually changed their strategy. But a comparison of the companies' strategy statements, between certain intervals (1985-2000), can give an indication of their intentions. In this paper, a company is considered to have a customer-focused strategy if the strategy contains some of following concepts: product development, higher margins, value-added products, and customer need. The absent and occurrence of product development in 1985 and in 2000 is also reviewed.

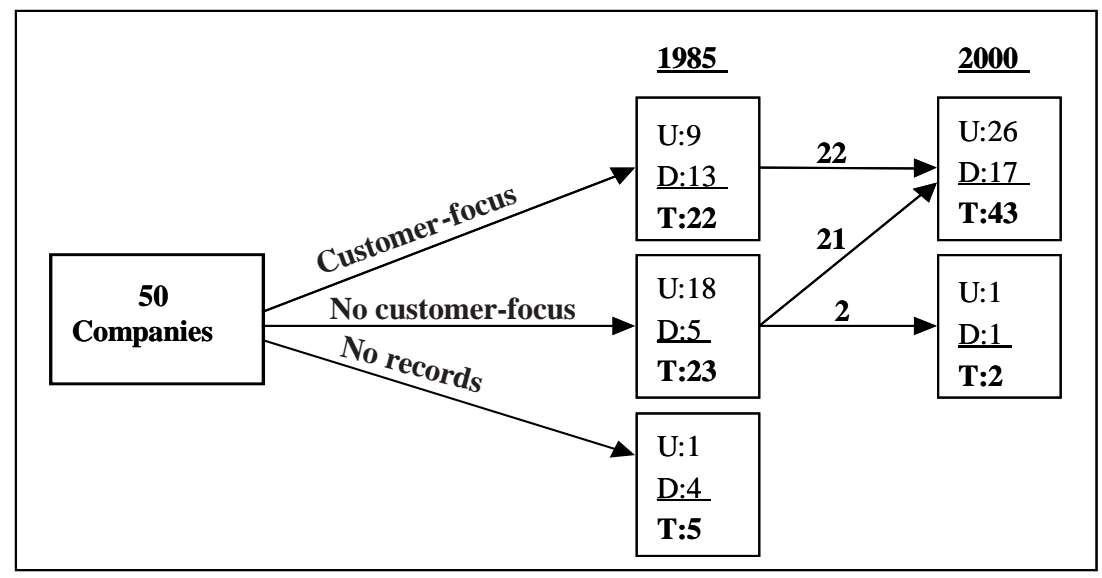

Fig. 6. The change of strategies for the 50 companies from 1985 to 2000. (U is upstream companies, $\mathrm{D}$ is downstream companies, and $\mathrm{T}$ is the total amount of companies in each group). 
The third part of the results focuses on the variables that indicate that there has been a shift of the centre of gravity for some companies in the study. The indicators are product type, development focus, customer cooperation, and use of cross-functional teams in development projects. These variables indicate that there has been a shift of mind for some process-based companies towards "downstream-thinking" (a shift of the centre of gravity).

The first indicator to investigate is the companies' type of product. According to the definition of an upstream company, it manufactures a standardized product. So, what type of product does the companies in the study manufacture? Table 4 shows the distribution of the tendency of increased product focus during the 90s and the companies' character of products, i.e. high-volume (standardized), niche (customized) or if they have a mixed product type, i.e. both high-volume and niche. The major difference here between upstream versus downstream companies is that it is more likely that an upstream company has a mix of high-volume products and niche products. 15 out of 28 (54\%) upstream companies emphasize the category "mixed", while it is only 4 out of $22(18 \%)$ for the downstream companies. However, altogether 20 (out of 28) upstream companies (71\%) and 20 (out of 22) downstream companies (91\%) indicate some degree of niche product focus today. Two downstream companies indicate a change from niche products to high-volume products today. This might depend on product maturity and increased competition.

There is an interest for upstream companies to find value-added niche products. Table 4 also shows that 17 out of 28 upstream companies (61\%) indicate an increase of product focus in their development work. The majority of the companies

Table 4. Number of companies in sample by increased product focus and product type (in 2000). U equals upstream companies and D equals downstream companies.

\begin{tabular}{llll}
\hline \hline \multirow{2}{*}{ Product Type } & \multicolumn{3}{c}{ Increased Product Focus } \\
\cline { 2 - 4 } & Yes & No & Total \\
\hline High-volume & U: 3 & U: 5 & U: 8 \\
& D: 0 & D: 2 & D:2 \\
Niche & U: 4 & U: 1 & U: 5 \\
& D: 6 & D: 10 & D: 16 \\
Mixed & U: 10 & U: 5 & U: 15 \\
& D: 3 & U: 1 & D: 4 \\
Total & U: 17 & U: 11 & U: 28 \\
& D: 9 & D: 13 & D: 22 \\
\hline \hline
\end{tabular}


that have not increased their product focus are downstream companies dealing with niche products, 10 out of 22 downstream companies (45\%). They already have a high level of product focus in their development projects. On the contrary, the majority of the companies that have increased their product focus are upstream companies with a mix of high-volume and niche products, 10 out of 28 upstream companies $(36 \%)$.

This indicator "product type" shows that the majority of the companies are not "upstreamers" today, i.e. traditional high-volume producers.

The second and third indicators to investigate are the companies' development focus and customer collaboration in projects. According to the definition of an upstream company, it is a low-cost producer and has its focus in process development, not in product development. Table 5 shows that only 4 out of 28 upstream companies (14\%) focus solely on process development. 24 (86\%) upstream companies mean that process and product development are at least equally important. This indicator "development focus" implies that the majority of the companies are not in their mind "upstreamers". According the definition of an upstream company, it focuses on technology know-how and not market skills. As Table 6 shows the majority of the upstream companies (24 out of 28 ,

Table 5. Number of companies in sample by focus in development and characteristic of the company (in 2000).

\begin{tabular}{lccr}
\hline \hline \multirow{2}{*}{$\begin{array}{c}\text { Focus in } \\
\text { Development }\end{array}$} & \multicolumn{3}{c}{ Characteristic of the Company } \\
\cline { 2 - 4 } & Upstream & Downstream & Total \\
\hline Product & 7 & 15 & 22 \\
Process & 4 & 0 & 4 \\
Equal & 17 & 7 & 24 \\
Total & 28 & 22 & 50 \\
\hline \hline
\end{tabular}

Table 6. Number of companies in sample by customer collaboration and characteristic of the company (in 2000).

\begin{tabular}{lrcr}
\hline \hline \multirow{2}{*}{$\begin{array}{c}\text { Customer } \\
\text { Collaboration }\end{array}$} & \multicolumn{3}{c}{ Characteristic of the Company } \\
\cline { 2 - 4 } & Upstream & Downstream & Total \\
\hline Yes & 24 & 22 & 46 \\
No & 4 & 0 & 4 \\
Total & 28 & 22 & 50 \\
\hline \hline
\end{tabular}


$86 \%$ ) indicate that it is important to have customer collaboration in development projects. This indicator shows that the majority of the upstream companies do not fit with the definition of an upstream company.

Traditionally, process-based companies do not need to integrate several functions in development work since the focus was in process development. However, the fourth indicator in the study, use of cross-functional teams, shows that $86 \%$ of the companies (43 out of 50) have cross-functional teams in development projects, see Table 7. Cross-functional teams can have various constellations with members from different functional areas. Since the companies studied are different, e.g. in size and available resources, the development teams can have different constellations. The definition here of a cross-functional team is that the team should both have a technical (e.g. production, development, material department) and a market input (e.g. marketing, sales, product department) into the project. In this research, there is no major different between upstream versus downstream companies.

Table 7. Number of companies in sample by cross-functional teams and characteristic of the company (in 2000).

\begin{tabular}{crcr}
\hline \hline \multirow{2}{*}{$\begin{array}{c}\text { Cross-Functional } \\
\text { Teams }\end{array}$} & \multicolumn{3}{c}{ Characteristic of the Company } \\
\cline { 2 - 4 } & Upstream & Downstream & Total \\
\hline Yes & 22 & 21 & 43 \\
No & 6 & 1 & 7 \\
Total & 28 & 22 & 50 \\
\hline \hline
\end{tabular}

None of the four variables above, selected to measure the current situation of Swedish process-based companies, were in coherence with the traditional view of a process-based company; standardized product, process development, and focus on technological know-how. The tables above indicate that there has been a "change of mind" for traditional upstream companies. But how can this change be illustrated? Figure 7 shows a matrix, which illustrates the companies' "change of mind" when it concerns development focus, customer collaboration, the use of cross-functional teams, and the strategy statements. If the company considers, at least, that product and process development are equally important and that it has both cross-functional teams and customer collaboration in development projects, then it is considered in this article a "change of mind". 


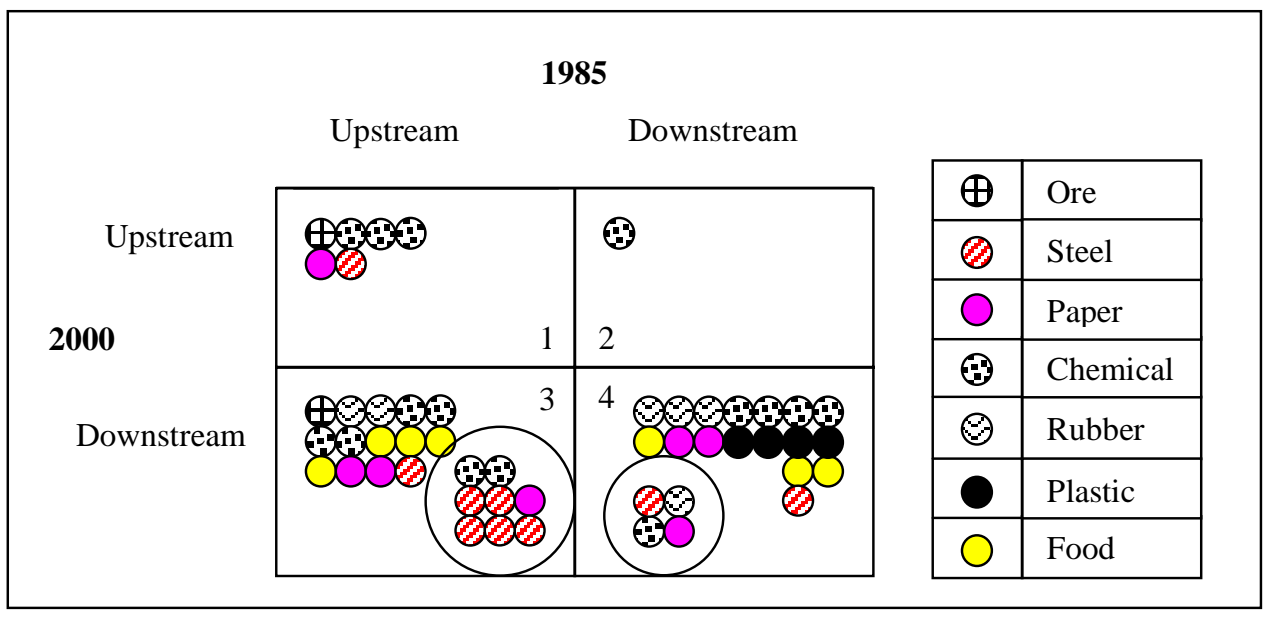

Fig. 7. The changed thinking for the companies when it concerns development focus, customer collaboration, cross-functional teams, and customer-focus in strategy statements. (There are special comments about the companies surrounded by a circle.)

\section{Comments About the Matrix}

The matrix has four quadrants and all of the 50 companies are positioned in it depending on their positions in 1985 and in 2000. The division of companies in upstream versus downstream is based upon the type of product the company had in 1985. However, this matrix is an attempt to view the companies "thinking" when it comes to development aspects like the development focus (that product and process development are at least equal important), customer collaboration in development projects, the use of cross-functional teams in development, and a customer-focus in strategy statements.

1. The six upstream companies (in ore, steel, paper, and chemical industry) in the first quadrant do not have cross-functional teams in development, however their strategies point out a change of focus towards customer-focus and valueadded for customers. Also, four of the companies do not have customer collaboration in the development projects. These six companies have not changed their working methods according to their indicated strategy. All but one company are just dealing with high-volume products, but three of the companies find at least that product and process development are equal important. A reason for still acting like an "upstreamer" is that it takes time to change working procedures and in some cases there is no need to have market input and incorporate customers in development projects due to the characteristics of the product, (e.g. petrochemical). 
2. This downstream company does not have customer-focus in its strategy statement and it produces a high-volume product today. A former niche product can become a "high-volume" product due to product maturity and increased competition.

3. One upstream company does not have customer-focus in the strategy statement, but indicate cross-functional teams, customer collaboration and product development focus. (No records of strategy for one of the upstream companies). The companies surrounded by a circle already had customer-focus in their strategy statements in 1985. A reason for the fact that 22 (out of 28) upstream companies have an urge to "become a downstreamer" can be the will to find specific niche products that gives higher margins and profits (and to maintain competitive). This requires new working methods and incorporation of customers in the development.

4. Four downstream companies have changed their strategy towards customerfocus (surrounded by a circle). One of them does not have cross-functional teams in 2000. The other companies had customer-focus in their strategy statements in 1985 (no records for four companies).

As the matrix shows, there is no major difference between the two groups, upstream versus downstream companies today. In 2000, $86 \%$ of the companies (43 out of 50) act, as they are downstream companies with some degree of product development focus, cross-functional teams and customer collaboration in development projects. However, there are some differences between the groups "upstream" and "downstream" when it concerns to the variables "type of product" and "development focus". The majority of the upstream companies (15 out of 28 , $54 \%$ ) produces both high-volume and niche products, see previous Table 4. But, the material indicates that there is an increased interest for upstream companies to develop niche products.

Further, the variable "development focus" also shows a difference between the two groups. An "upstreamer" is more likely to emphasize equal development focus, 17 out of 28 companies (61\%), i.e. product and process development are equally important. Only 7 out of 22 downstream companies (32\%) find them equally important. They emphasize product development, see previous Table 6 .

Finally, the fourth part of the results is a summary of some of the results stated above. Since there is a change for the majority of the process-based in this research, there is a need for improved integration between resources and activities in development today. This need for integration of various activities is shown in the need of cross-functional teams and improved links to both customers and suppliers. However, Table 8 shows that there is a low number of companies that feel a need for improved networks - 6\% (only 3 out of 50 companies). But as 
Table 8. The different needs/changes in the future for the companies.

\begin{tabular}{lcccccccc}
\hline \hline \multicolumn{7}{c}{ Future Needs in Development } \\
$\begin{array}{l}\text { Type of } \\
\text { Industry }\end{array}$ & $\begin{array}{c}\text { Continuous } \\
\text { Change }\end{array}$ & $\begin{array}{c}\text { Decrease } \\
\text { Costs }\end{array}$ & $\begin{array}{c}\text { Customer } \\
\text { Collaboration }\end{array}$ & $\begin{array}{c}\text { Supplier } \\
\text { Collaboration }\end{array}$ & $\begin{array}{c}\text { Data- } \\
\text { bases }\end{array}$ & $\begin{array}{c}\text { Competence/ } \\
\text { Knowledge }\end{array}$ & Networks & Other \\
Needs
\end{tabular}

many as $24 \%$ feel that collaboration with customers could be better (12 out of 50 companies).

What has happened in process industries during the 90s? Have process industries in Sweden diversified to related business, which is shown in an increase of product development efforts and change of strategy? Have the companies changed their strategy towards diversification?

No, none of the companies in the research have indicated a diversification to other businesses or changed the product mix. On the contrary, 8 upstream companies have focused their businesses (i.e. decreased the range of product groups) to enable an increased effort in product development for certain product groups that are interrelated, see Table 9. There is also an emphasis today to sell more than just the physical product. The meaning of "a package" in this study is that developers need to have knowledge about customers' processes, to help the customers use the product, to teach customers of the use of the product, to test the product in the customers' processes. The product package can include service attached to the product, support activities etc. 19 upstream companies

Table 9. Number of companies in sample by focused business and characteristic of the company.

\begin{tabular}{cccc}
\hline \hline \multirow{2}{*}{$\begin{array}{c}\text { Focused Business } \\
\text { During the 90th }\end{array}$} & \multicolumn{3}{c}{ Characteristic of the Company } \\
\cline { 2 - 4 } & Upstream & Downstream & Total \\
\hline Yes & 8 & 2 & 10 \\
No & 20 & 20 & 40 \\
Total & 28 & 22 & 50 \\
\hline \hline
\end{tabular}


Table 10. Number of companies in sample by product content and characteristics of the company.

\begin{tabular}{lccc}
\hline \hline \multirow{2}{*}{$\begin{array}{l}\text { Product } \\
\text { Content }\end{array}$} & \multicolumn{3}{c}{ Characteristic of the Company } \\
\cline { 2 - 4 } & Upstream & Downstream & Total \\
\hline Physical & 9 & 10 & 19 \\
Package & 19 & 12 & 31 \\
Total & 28 & 22 & 50 \\
\hline \hline
\end{tabular}

(68\%) and 12 downstream companies (55\%) include more than just the physical product in their development today (Table 10).

\section{Discussion and Future Directions}

The findings of this research contribute to the existing body of product development research in at least two ways. A first contribution concerns the implication of a change strategy with the focus on higher margins, proprietary products, and customer needs for process industries. The second contribution is the test of the situation of Swedish process industries, towards "downstreamthinking, based on Galbraith's (1983) centre of gravity approach. He argues that it is very difficult to achieve a change from being an upstream to a downstream company. To be able to discuss the subject above, following questions are posed:

- What has changed in development concerning project work and collaboration for companies in various process industries during the last decade?

- What are the implications of this change of a more customer-oriented view in development for process industries?

Today, there are two dimensions that enable product development in process industries. At one end of the spectrum, individual customer demands can enable major changes concerning product concepts and modifications of existing products. Various organization and action programs to shorten development time support that approach (Utterback, 1996). At the other end of the spectrum, there is process development, i.e. the know-how in the technology. The development of production processes is mainly based on improvements and major market evolutions. The most important factors in process development are; reduction of production costs, improvement of production volumes and product recoveries, and to make a more environment-friendly production. 
For process-based companies, it can be easier to change the basic characteristics of their production equipment that enable new product ideas than to start with a new product concept without process development. Their production processes are often too inflexible to manufacture a range of different products.

The first contribution of the research was to investigate how the four factors: product type, development focus, customer collaboration, and the use of crossfunctional teams in development projects are indicators that upstream companies are headed towards the same perspective in development issues as downstream companies. This change of perspective will imply a change of gravity, i.e. that other aspects are of interest in development work and this means that other working methods and networks must be implemented and understood. As a result the change of perspective must be enhanced to a managerial level of strategic renewal, see Fig. 8.

Another influential factor on strategic change, that must not be neglected, is the impact of information technology. It has come to influence all types of organizations during the 90s. It is shown in the study that information technology facilitates cooperation and information distribution/sharing. There is an increased use of e.g. databases in development projects today. However, the focus of this paper is not to elaborate this matter any deeper ${ }^{2}$.

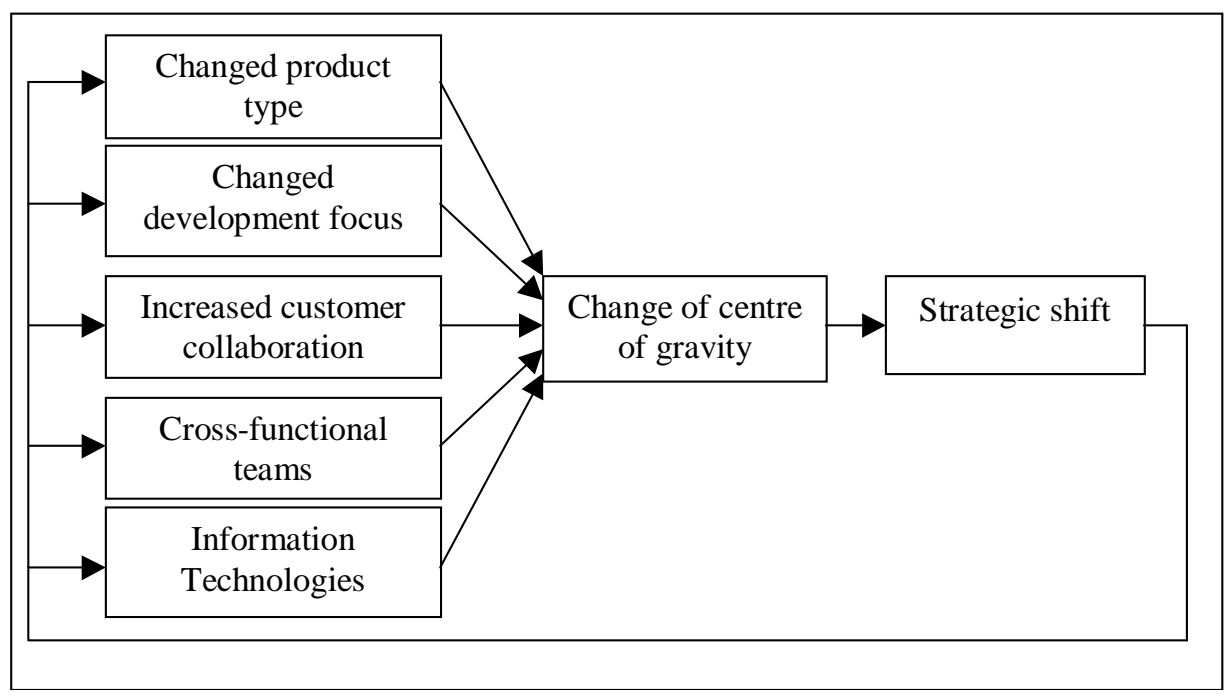

Fig. 8. The framework of the research.

\footnotetext{
${ }^{2}$ It is under elaboration in an additional paper, Chronéer, D., 2002 "Future relationships and networks in development work for process industries".
} 
There is a trend towards a more customer-oriented view within Swedish process industries, but what has explicitly changed in development work for companies in various process industries during the last decade? The result of this research shows that process industries no longer solely focus on development of the production processes, i.e. on technological issues that implies a defensive product development strategy (Utterback, 1996). Today, there are two roads to choose between for process industries, either to maintain a high-volume producer and have a cost-effective production processes, or to focus the business and find niche products that generate higher margins and profitability.

Many Swedish process industries choose the road to focus their businesses and develop higher margin products, because it is difficult to compete with lowcost countries. It has to be stated, that one major cause of the change is that, from a perspective of 20-25 years, there is an obvious change in the trend of the economical development for process industries in Sweden, a diminished consumption of e.g. steel products and an increased competition. Also, at the end of the 1980's and during the 90s the restructuring of the industry had resulted in a new ownership structure (mergers, acquisitions etc), which encompassed a wide spectrum of companies - from international giants to small-specialized niche producers.

Today, it is possible to develop more specific products due to the fact that customers demand more value-added products. This has led to an increased emphasis, for Swedish process industries, in product development, which is shown in a changed product type, changed development focus, and increased customer collaboration in development projects.

The first change for traditional Swedish upstream companies is the change of the product type since the customers play a more distinguished role today in development than for 10-15 years ago. There is an increased focus to find niche products that can generate higher margins for the companies. This has led to that the concept of the product has changed. Today it can contain services or competence attached to the product (sell a package). It can concern selling developing hours or other services connected to the customers' production processes.

The second change concerns the changed perspective in development. The effect of develop niche products is that developers need to attach other knowledge in development projects today. Developers are required to have knowledge about customers' processes, markets etc. to enable a more effective development exchange and sophisticated products. For example, it is required to visit customers at their own workshops to be able to show benefits of the product, the product's material properties. There are other aspects (new knowledge) that need to be included in development today, which a traditional development team does not 
have. This new knowledge must be acquired ether internal or external. Development has another context today, e.g. development of services or competence attached to the product (sell a package).

A third important change for traditional Swedish upstream companies is the need to collaborate with customers and with other actors that can contribute with new knowledge into development projects. It is also indicated in the study that it is desirable to have customer collaboration early in product development projects. The research shows that there are an increased number of upstream companies that collaborate with customers in development projects. A large amount of the companies have undergone organizational changes during the last decade in order to create suitable integration mechanism to the market and the customers. It is essential to have a formalized link to the customers. This link can take different forms. The responsibility can be on

- development, i.e. a direct link to customers, especial when development concerns competence and service,

- marketing (with technical competence), i.e. marketing is the facilitator between development and the customers,

- technical service, i.e. technical personnel that have competence in both development issues and market aspects.

A fourth change is the need of cross-functional teams in development work today. As research has shown, collaboration in any form is often important, i.e. $\mathrm{R} \& \mathrm{D} /$ manufacturing/marketing integration, $\mathrm{R} \& \mathrm{D} /$ marketing integration, partnerships with supplier, customer integration, and strategic partnership. Collaborations in all forms are increasingly playing a major role in process industries. One reason can be that human resources are seen as more valuable today for companies. Another reason can be that there has been an extended amount of research on collaboration during the last decades and that team members have changed their attitudes towards cross-functional work. A third reason can be that it is easier to collaborate today due to information technologies.

But not only is the integration of internal functions important, integration of external actors like suppliers and customers have been emphasized in process industries during the 1990s. So, to have a network perspective can facilitate the analysis and understanding of critical actors in development work, which continuously change. Links to new competences and new knowledge that the product developer does not have must continuously be analysed and evaluated so that product development will be effective.

To change the view in product development projects, from production-oriented to be more customer-oriented, also involve a change in management and 
organization of the project. The change of mind concerning a focus towards product development will have implications on future strategy for the company.

The implication of the change for an upstream company is that it is closing the gap to a downstream company. The procedures and management of development tend to be the same for both an upstream company and a downstream company. To make a distinction between companies today in terms of upstream and downstream is of no relevance. The specific characteristics between the two groups that Galbraith (1983) emphasizes have changed.

The second contribution of this research is the argument that there is a change for process industries concerning the change of focus in the value chain, which is not easily obtained. The industry's centre of gravity will affect the efforts to change procedures. Because this gravity is well rooted in the management and organization of projects (Galbraith, 1983). For process industries, this gravity is much focused on the production process and not the customers (see also Fig. 9).

Further, the results indicate a shift of the centre of gravity since there is an increased interest in product development and customer collaboration.

Today, it is not possible to divide companies according to traditional "upstream" characteristics as standardized product, low-cost producer etc. The result of the research indicates that upstream companies

- strive to gain higher value-added in their products by changing the concept of the product (e.g. selling competence and service),

- need to collaborate with customers in development projects,

- need to find suitable networks that integrate knew knowledge to development projects

- need to work with cross-functional teams in development

The main message in this research it is possible to be a traditional upstream company, but with a combination of product and process development.

But a changed product concept will have implications on the structure of networks and how to integrate resources and activities connected to development work. A general conclusion is that personal contact is the integration mechanism product development teams require to build trust and longsighted relationships with key suppliers and customers. However, this is both time-consuming and requires resources. Much of the network buildings are depending on the individual itself in development team. But, it is important that the company have a clear strategy concerning the importance and possible links to both suppliers and customers. If the link between a customer and development is through sales, marketing or technical service than this function needs to be known as a formalized facilitator in the development work. 


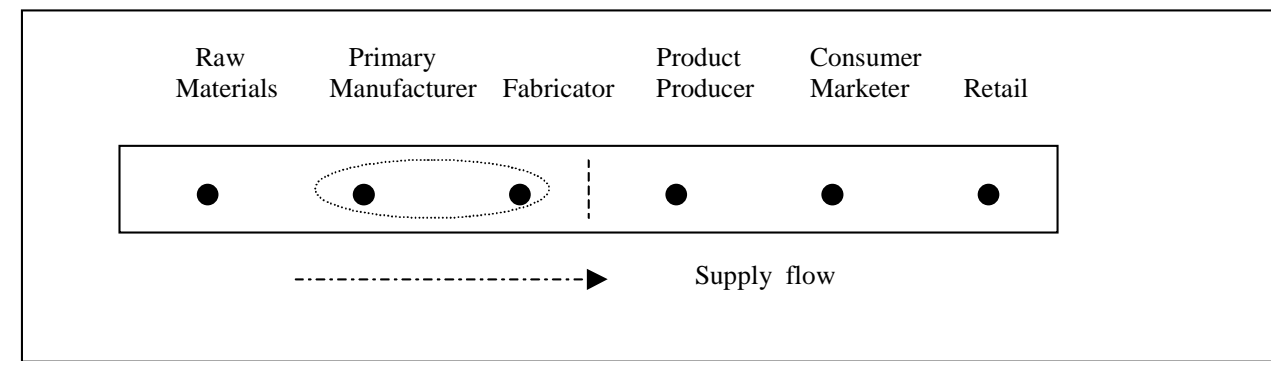

Fig. 9. The centre of gravity for steel and paper industries (source Galbraith \& Kazanjian, 1986).

In sum, process industries in Sweden have shifted their "upstream-thinking" to "downstream-thinking", which implies new managerial systems and closer links to customers and process industries in Sweden have moved downstream, away from low margins and high capital intensity into higher margin, proprietary products. It implies a shift of the companies' centre of gravity.

Today, technical changes are happening rapidly, therefore it is of more importance for companies to build sustainable relationship with suppliers of equipment and processes. This is critical for traditional upstream companies if they need to keep up with technological changes in customers' production processes. However, network activities in development are increasing for process industries, there are no longer separate supplier vs. customer development. In many cases the companies view their suppliers as an integrated part of their own product flow process. The study indicates that all industries have the need to build sustainable networks. The principal point is to build networks of capabilities. Managers have to build formalized integration mechanisms to involve both suppliers and customers earlier and more deeply in the development process because much of networking in process industry is of personal basis. This requires a deep analysis of both suppliers and customers. The change of gravity will have implication of the strategy of the company, i.e. a strategic shift must be analysed and evaluated from the management.

Certain limitations of the study suggest directions for future research. The research is limited to companies in Sweden, but there is indication that this is not just an isolated phenomenon. However, international research on this matter as comparison is a future research topic. How process industries will manage production flexibility and product differentiating is an area that needs further research in the future. 


\section{Appendix A}

The areas of changes within ore $(\mathrm{O})$, steel $(\mathrm{S})$, paper $(\mathrm{Pa})$, chemical $(\mathrm{C})$, rubber $(\mathrm{R})$, plastic $(\mathrm{Pl})$, and food $(\mathrm{F})$ industry during the 1990s. One company can address several changes in the table.

\begin{tabular}{|c|c|}
\hline $\begin{array}{l}\text { The areas of } \\
\text { changes }\end{array}$ & $\begin{array}{l}\text { Comments about the actual changes concerning development work } \\
\text { at the companies in the study }\end{array}$ \\
\hline $\begin{array}{l}\text { Product } \\
\text { development } \\
\text { focus }\end{array}$ & $\begin{array}{l}\text { Develop better products due to new knowledge }(\mathrm{O}) \\
\text { Focus on niche products, specialized on material with unique properties }(\mathrm{R}) \\
\text { Change towards niche products }(\mathrm{C}) \\
\text { Increased number of niche products }(\mathrm{F}, \mathrm{Pa}, \mathrm{S}) \\
\text { Development of new properties }(2 \mathrm{~F}) \\
\text { Increased product development focus and efforts }(2 \mathrm{~Pa}, 2 \mathrm{Pl}, 4 \mathrm{~S})\end{array}$ \\
\hline $\begin{array}{l}\text { Product } \\
\text { concept }\end{array}$ & $\begin{array}{l}\text { Sell development hours, integrate forward in the value chain with assembly } \\
\text { and packaging combined to the product (R) } \\
\text { Work with customers processes, has gained increased knowledge about } \\
\text { customers' processes }(\mathrm{C}, \mathrm{Pl}) \\
\text { Sell all products with technical service in a "package" even with niche } \\
\text { products }(\mathrm{C}) \\
\text { Sell a complete concept, the experience, are "problem solvers" ( } 2 \mathrm{C}) \\
\text { Have increased responsibility of customers' development, sell a complete } \\
\text { package with competence and a product. (Pl) } \\
\text { Put price on customer profit (S) } \\
\text { Increased personal service to customers, learn them to use the product (S) }\end{array}$ \\
\hline Organization & $\begin{array}{l}\text { Early line organization, now project organization with project leader (R) } \\
\text { Flat organization (R) } \\
\text { Organization towards specialization of material (R) } \\
\text { Organizational changes toward focusing the business, clear link between } \\
\text { development and sale personnel, through Project Manager (gather } \\
\text { information and analyse the market) (R) } \\
\text { Link development labs within the Group together to achieve economy- } \\
\text { of-scale (C) } \\
\text { Project organization (C) } \\
\text { Continuous change due to changed needs from customers and the } \\
\text { company (C) } \\
\text { Organizational change due to focus on concept development (C) } \\
\text { A division in technique divisions to enable focusing in product areas, } \\
\text { channels to customers has changed, development closer to customers (C) } \\
\text { Changed product development work to be the same in the whole Group (F) } \\
\text { Direct link between development and marketing (F) } \\
\text { Changed marketing function (F) } \\
\text { Merger with company (F) } \\
\text { Increased resources at development department with organized } \\
\text { product development, merger with company (F) }\end{array}$ \\
\hline
\end{tabular}




\begin{tabular}{|c|c|}
\hline $\begin{array}{l}\text { The areas of } \\
\text { changes }\end{array}$ & $\begin{array}{l}\text { Comments about the actual changes concerning development work } \\
\text { at the companies in the study }\end{array}$ \\
\hline Organization & $\begin{array}{l}\text { Centralized product development to gain economy-of-scale (F) } \\
\text { Marketing, sale and product development work closely together to make } \\
\text { product development more effective (F) } \\
\text { Division in three R\&D sections: product development, process development } \\
\text { and strategic development plus a section that do customer projects in } \\
\text { cooperation with the other sections (Pa) } \\
\text { Decentralized R\&D organization, a Technology centre work closely with } \\
\text { development at production sites, merger. (Pa) } \\
\text { Decentralize development closer to market units (Pa) } \\
\text { Organizational change with the focus on product development process (Pa) } \\
\text { Organizational fit within the divisions, continuous change (Pl) } \\
\text { Changed organization (Pl) } \\
\text { Decentralized product development, shorten communication ways (S) } \\
\text { Technical market support, support activities towards customers and } \\
\text { marketing (S) } \\
\text { Changed product development from technical department to } \\
\text { marketing department (S) } \\
\text { Delegate responsibility to units (S) } \\
\text { Sale organization contact with customers' engineers, education of } \\
\text { customers engineers (S) }\end{array}$ \\
\hline Project work & $\begin{array}{l}\text { Team-building (R) } \\
\text { IT-links that create virtual work groups to enable exchange of information. } \\
\text { The Group has common IT platforms that enable project sharing }(\mathrm{C}) \\
\text { Change in documentation of projects }(\mathrm{C}) \\
\text { Project management, planning and control of projects }(\mathrm{C}) \\
\text { Functional food and behaviour science more important }(\mathrm{F}) \\
\text { Health, convenience, development consist of more today, more niche } \\
\text { products, combination of marketing and the content of the product, } \\
\text { packaging more important }(\mathrm{F}) \\
\text { More structure in product development }(\mathrm{F}) \\
\text { Packaging more important }(\mathrm{F}) \\
\text { Increased market input to development projects }(\mathrm{Pa}) \\
\text { Changed working methods, cross functional teams (Pa) } \\
\text { Control pf projects (Pa) } \\
\text { Made product developer to market technicians to catch customer needs } \\
\text { and communicate with procurement and technique at customers }(\mathrm{Pl}) \\
\text { Databases to systematize projects }(\mathrm{O}, 4 \mathrm{C}, 2 \mathrm{~S})\end{array}$ \\
\hline
\end{tabular}




\begin{tabular}{|c|c|}
\hline $\begin{array}{l}\text { The areas of } \\
\text { changes }\end{array}$ & $\begin{array}{l}\text { Comments about the actual changes concerning development work } \\
\text { at the companies in the study }\end{array}$ \\
\hline $\begin{array}{l}\text { Customer/ } \\
\text { supplier } \\
\text { collaboration }\end{array}$ & $\begin{array}{l}\text { Focus on few customers (R) } \\
\text { Customers have changed }(\mathrm{C}) \\
\text { Customers are involved earlier in projects }(\mathrm{C}) \\
\text { Work more independent with customers }(\mathrm{C}) \\
\text { Work more closely with customers and suppliers }(\mathrm{C}) \\
\text { Focus on suppliers of parts }(\mathrm{C}) \\
\text { Development projects with suppliers }(\mathrm{C}) \\
\text { More flexibility and quicker response on customer's need (F) } \\
\text { Raw material suppliers are viewed as a resource that can decrease } \\
\text { product development time (F) } \\
\text { Increased customer collaboration to gain insight of customer problems and } \\
\text { their product development (Pa) } \\
\text { More efficient input from customers to projects (Pa) } \\
\text { Increase productivity at customer's process, higher demands on supplier } \\
\text { collaboration in projects }(\mathrm{Pa}) \\
\text { Increased customer-focus in projects (Pl) } \\
\text { Increased collaboration with customers (Pl) } \\
\text { Towards customer demands }(\mathrm{S})\end{array}$ \\
\hline
\end{tabular}

\section{References}

Araujo, L., Dubois, A. \& Gadde, L. (1999) Managing interfaces with supplier. Industrial Marketing Management, 28(5), 497-506

Bruce, M., Leverick, F., Littler, D. \& Wilson, D. (1995) Success factors for collaborative product development: A study of suppliers of information and communication technology, $R \& D$ Management, 25(1), 33-44

Butscher, S. \& Laker, M. (2000) Market-driven product development. Marketing Management, 9(2), 48-53

Campbell, A.J. \& Cooper, R.G. (1999) Do customer partnerships improve new product success rates? Industrial Marketing Management, 28, 507-519

Comer J.M. \& Zirger, B.J. (1997) Building a supplier-customer relationship using joint new product development. Industrial Marketing Management, 26, 203-211

Dwivedi, S.N. \& Sharma, J.P. (2002), Role of customers in the development of innovative process and product. International Journal of Computer Applications in Technology, 15(1/2/3), 24-36

Etienne, E.C. (1981) Interactions between product R\&D and process technology. Research Management. January, 22-27

Fischer, R. J., Maltz, E. \& Jaworski, B.J. (1997) Enhancing communication between marketing and engineering: The moderating role of relative functional identification. Journal of Marketing, 61(3), 54-70 
Galbraith, J.R. (2002) Organizing to deliver solutions. Organizational Dynamics, 31(2), 194-207

Galbraith, J. (1983) Strategy and organization planning. Human Resource Management, 22(1/2), 63-77

Galbraith, J.R. \& Kazanjian, R.K. (1986) Strategy Implementation: Structure, Systems and Process. St. Paul: West Publishing Company

Griffin, A. \& Hauser, J.R. (1993) The voice of the customer. Marketing Science, 12(1), $1-27$

Griffin, A. \& Hauser, J.R. (1996) Integrating R\&D and marketing: A review and analysis of the literature. Journal of Product Innovation Management, 13, 191-215

Gruner, K.E. \& Homburg, C. (2000) Does customer interaction enhance new product success? Journal of Business Research, 49, 1-14

Håkansson, H. (1990) Product development in networks. In Understanding Business Markets, Interaction, Relationships, networks, ed. D. Ford, pp. 487-507. London: Academic Press

Harkins, J.R. \& Dubreuil, M.P. (1993) Concurrent engineering in product design/development. Plastics Engineering, 49(August), 27-31

Hartley, J.L., Meredith, J.R., McCutheon, D. \& Kamath, R.R. (1997) Suppliers' contribution to product development: An exploratory study. IEEE Transactions on Engineering Management, 44(3), 258-266

Heinonen, J. (1994) Model of customer oriented product development systematics - and its testing in petrochemical industry. Tampere University of Technology, Publication No.143, Finland

Huang X., Steffens P. \& Schroder, B. (2002) Managing new product development in the chinese steel industry: An empirical investigation. International Journal of Technology Management, 24(5/6), 557-568

Ilinitch, A.Y. \& Zeithaml, C.P. (1995) Operationalizing and testing Galbraith's centre of gravity theory. Strategic Management Journal, 16, 401-410

Ita, P.A. \& Gross, A.C. (1995) Industry corner: World rubber and tire. Business Economics, 30(1), 58-63

Lager, T. (2002) Product and process development intensity in process industry: A conceptual and empirical analysis of the allocation of company resources for the development of process technology. International Journal of Innovation Management, 6(2), 105-130

Littler, D. \& Leverick, F. (1995) Joint ventures for product development: Learning from experience. Long Range Planning, 28(3), 58-67

Kahn, K.B. (2001) Market orientation, interdepartmental integration, and product development performance. Journal of Product Innovation Management, 18, 314-323

Kärkkäinen, H., Piippo, P. \& Tuominen, M. (2001) Ten tools for customer-driven development in industrial companies. International Journal of Production Economics, 69, 161-176

Magrath, A.J. \& Hardy, K.G. (1994) Building customer partnerships. Business Horizons, 37(1), 24-27 
Mello, S. (2001) Right process, right product. Research Technology Management, 44(1), $52-58$

Olson, E.M., Walker, Jr. O.C., Ruekert, R.W. \& Bonner, J.M. (2001) Patterns of cooperation during new product development among marketing, operations and R\&D: Implications for project performance. Journal of Production Innovation Management, 18, 258-271

Ottum, B. D. \& Moore, W.L. (1997) The role of market information in new product success/failure. Journal of Product Innovation Management, 14, 258-273

Pick, P. (1999) Building customer-supplier relationship in electronics. Long Range Planning, 32(2), 263-272

Porter, M.E. (1985) Competitive Advantage, New York: Free Press

Ragatz, G.L., Handfield, R.B. \& Scannell, T.V. (1997) Success factors for integrating suppliers into new product development. Journal of Product Innovation and Management, 14, 190-202

Rajagopalan, N. \& Spreitzer G.M. (1996) Towards a theory of strategic change: A multilens perspective and integrative framework. Academy of Management Review, 22(1), 48-79

Rumelt, R.P. (1986) Strategy, Structure, and Economic Performance. Boston, Massachusetts: Harvard Business School Press

Smith, P.G. \& Reinertsen, D.G. (1998) Developing Products in Half the Time. New York: Van Nostrand Reinhold

Song, X.M., Thieme, R.J. \& Xie, J. (1998) The impact of cross-functional joint involvement across product development stages: An exploratory study. Journal of Product Innovation Management, 15, 289-303

Song, X.M., Montoya-Weiss, M.M. \& Schmidt, J.B. (1997) Antecedents and consequences of cross-functional cooperation: A comparison of $\mathrm{R} \& \mathrm{D}$, manufacturing, and marketing perspectives. Journal of Product Innovation Management, 14, 35-47

Song, X. M., Neeley, S.M. \& Zhao, Y. (1996) Managing R\&D-marketing integration in the new product development process. Industrial Marketing Management, 25(6), $545-553$

Swink, M. and Mabert, V. (2000) Product development partnerships: Balancing the need of OEMs and suppliers. Business Horizons, 43(3), 59-68

Utterback, J.M. (1996) Mastering the Dynamics of Innovation. Boston: Harvard Business School Press 
Copyright $\odot 2003$ EBSCO Publishing 